\title{
Vulvovaginal Complaints
}

\section{Chelsea Bayer, MD \\ Laura Parks, $M D^{*}$}

\author{
Address \\ *Washington University School of Medicine, St. Louis, MO, USA \\ Email: parksla@wudosis.wustl.edu
}

Published online: 26 July 2016

C Springer International Publishing AG 2016

This article is part of the Topical Collection on Pediatric Gynecology

Keywords Vulvar care $\cdot$ Pediatrics $\cdot$ Vulvovaginitis $\cdot$ Hygiene $\cdot$ Treatment

\section{Opinion statement}

Teaching patients the proper vulvar care is the first, and arguably the most important, aspect of treating vulvovaginal complaints in the pediatric population. Other treatments, which will be discussed in this chapter, will be less effective with a high risk of recurring symptoms if the patient and her parents do not adopt good vulvar care habits. Vulvovaginitis usually can be managed with conservative measures, including proper hygiene and education on vulvar care guidelines. These include avoiding chemical irritants and excessive hygiene, wearing white cotton underwear, avoiding dryer sheets, wiping from front to back, and limiting tight-fitting clothing. Additionally, it is important to discuss bathing, including recommending showers or baths without soaps and bubble products. If both the child and the parents follow these simple rules, the vast majority of vulvovaginal complaints will dramatically improve. Consistently following the vulvar care guidelines will not only help relieve the symptoms of itching and irritation but will also aid in the healing and treatment of vulvovaginitis. If the girl is infected with a specific organism, the treatment should be directed at that organism, and the girl should be educated on proper vulvar care. Finally, any condition that requires topical steroid ointment or simple barrier creams will be treated more quickly and effectively when good vulvar hygiene is added to the treatment regimen.

\section{Introduction}

Vulvovaginal complaints are the most common reasons for a young girl to see a pediatric gynecologist [1]. Vulvovaginitis describes conditions in which either the external genitalia, the vagina, or both are inflamed, irritated, pruritic, or erythematous [2]. Such conditions are commonly caused by irritation from chemicals such as scented soaps or detergents, poor hygiene, or excessive hygiene. In addition to a tendency towards poor perineal hygiene, young girls are also more susceptible to generic vulvovaginal complaints than their postpubertal counterparts. This is because pre-pubertal girls have a nonestrogenized vaginal mucosa with a more alkaline $\mathrm{pH}$, lack labial development, and lack pubic hair, which provide a protective barrier [3]. 
A complete history is essential to treating vulvovaginal complaints and can help the physician decide whether more extensive treatment or intervention is necessary. In addition to helping the physician develop a differential diagnosis, a history is important as children may misinterpret urinary or bowel complaints as vulvovaginal complaints. The patient and her parents should be asked questions about hygiene, possible exposures to irritating chemicals, timing of itching, and possible foreign bodies that may have been inserted into the vagina, most commonly toilet paper. Chronic selfstimulatory habits can lead to thickening of the clitoral hood and, consequently, to non-specific vulvovaginal complaints in pre-pubertal children. Finally, the physician should always keep in mind that sexual abuse can lead to vulvovaginitis. Taking the time to obtain a thorough history can help identify common triggers or causes of the vulvovaginitis and prevent unnecessary tests or treatments.

The two most common causes of vulvovaginitis are local irritants and foreign bodies; infection is a distant third [4]. Most common causes of infection include streptococcus pyogenes [5], pinworms, candida, or sexually transmitted infections. Non-sexually transmitted vulvar ulcers or aphthous ulcers (Fig. 1) are unique in that they are generally quite painful and often paired with systemic symptoms such as fever, fatigue, and malaise [6]. Cutaneous vulvar disorders, such as lichen sclerosis (Fig. 2) or labial adhesions (Fig. 3), are a less common cause of vulvovaginal complaints but need to remain on the differential, especially in the setting of refractory symptoms. Diagnosis and treatment of these

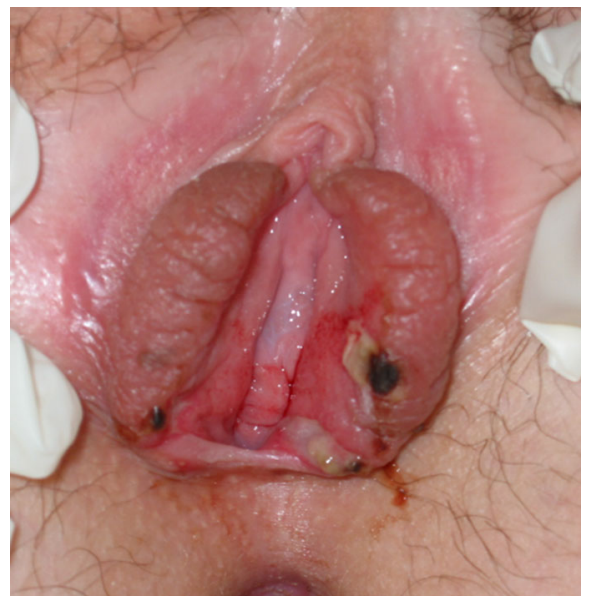

Fig. 1. Aphthous ulcers (Photo by Diane F. Merritt MD)

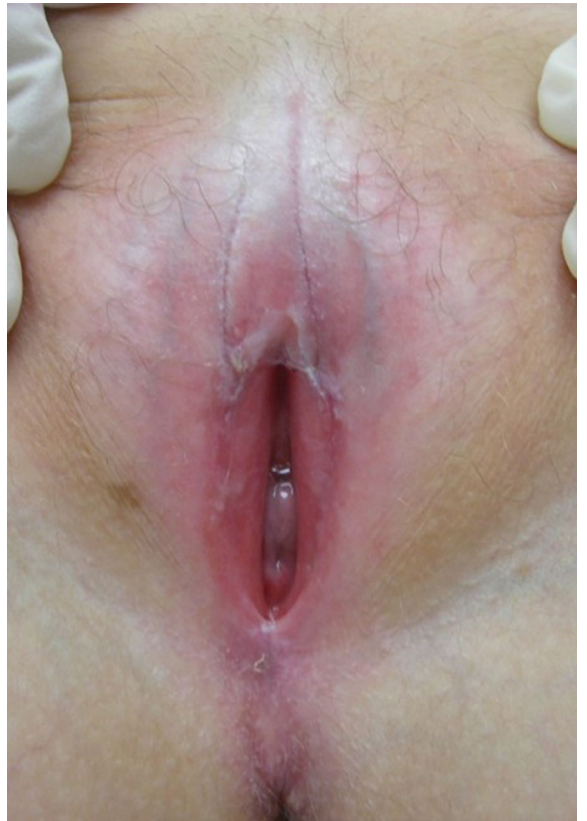

Fig. 2. Lichen Sclerosus (Photo by Diane F. Merritt MD)

specific causes of vulvovaginitis and some less common causes are outlined in Table 1 below.

Because local irritation is the most common cause of vulvovaginitis, treatment is commonly conservative with a behavioral component to improve symptoms. Treatment is based almost entirely on education and

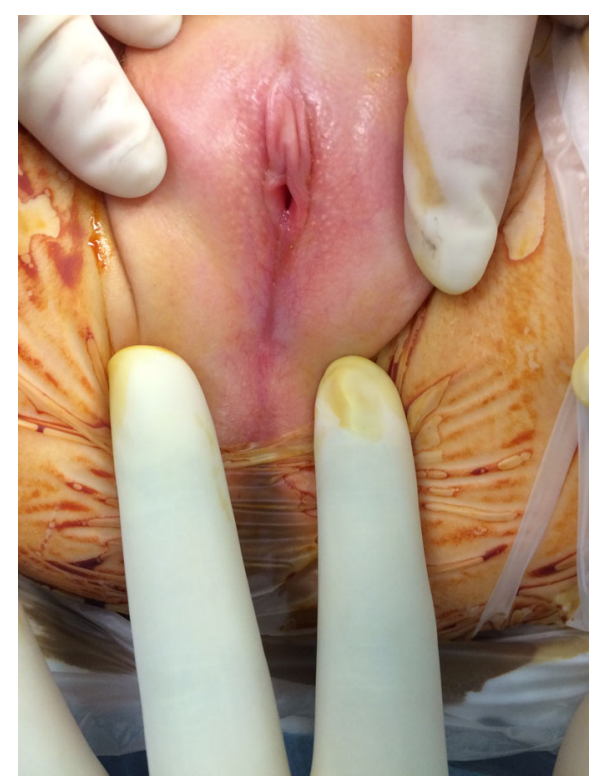

Fig. 3. Labial adhesions (Photo by Laura A. Parks MD) 
Table 1. Vulvovaginal complaints and treatment

\begin{tabular}{|c|c|c|c|}
\hline Cause & Presentation & Diagnosis & Treatment \\
\hline $\begin{array}{l}\text { Atopic } \\
\text { dermatitis }\end{array}$ & $\begin{array}{l}\text { Itching, skin dryness, } \\
\text { erythema, oozing } \\
\text { and crusting, and } \\
\text { lichenification }\end{array}$ & $\begin{array}{l}\text { Clinical diagnosis based on } \\
\text { history and morphology } \\
\text { of lesions }\end{array}$ & $\begin{array}{l}\text { Vulvar care guidelines, } \\
\text { topical steroids for } \\
\text { flare-ups }\end{array}$ \\
\hline Candida & $\begin{array}{l}\text { Uncommon in prepubertal } \\
\text { girls, usually with recent } \\
\text { antibiotic use or who are } \\
\text { immunosuppressed. Itching } \\
\text { and discharge [7]. }\end{array}$ & $\begin{array}{l}\text { Candida seen on wet } \\
\text { prep, fungal culture }\end{array}$ & Fluconazole or miconazole \\
\hline $\begin{array}{l}\text { Condyloma } \\
\text { acuminata }\end{array}$ & $\begin{array}{l}\text { Skin-colored flattened } \\
\text { papules often with } \\
\text { cauliflower or smooth } \\
\text { appearance }\end{array}$ & $\begin{array}{l}\text { Visual inspection, HPV } \\
\text { testing not helpful. } \\
\text { Biopsy only if diagnosis } \\
\text { is questionable [8]. }\end{array}$ & $\begin{array}{l}\text { Observation and trichloroacetic } \\
\text { acid. Imiquimod therapy may help. } \\
\text { Surgical management with laser or } \\
\text { cryotherapy is an option [9]. }\end{array}$ \\
\hline $\begin{array}{l}\text { Contact } \\
\text { dermatitis }\end{array}$ & $\begin{array}{l}\text { Erythematous and edematous, } \\
\text { rarely with vesicles or pustules. }\end{array}$ & $\begin{array}{l}\text { Localized irritation } \\
\text { with exposure to irritant }\end{array}$ & Vulvar care guidelines, topical steroids \\
\hline Foreign Body & $\begin{array}{l}\text { Chronic discharge, occasional } \\
\text { vaginal bleeding, foul- } \\
\text { smelling odor }\end{array}$ & $\begin{array}{l}\text { Visual inspection and history. } \\
\text { May require exam under } \\
\text { anesthesia. }\end{array}$ & $\begin{array}{l}\text { If specimen is visualized, may } \\
\text { remove in office with swab or } \\
\text { irrigation with warm water. Exam } \\
\text { under anesthesia may be necessary. }\end{array}$ \\
\hline Herpes Simplex & $\begin{array}{l}\text { Vesicular ulcers or blisters } \\
\text { that tend to break open }\end{array}$ & Culture from lesion & Acyclovir \\
\hline $\begin{array}{l}\text { Labial } \\
\text { Adhesions } \\
\text { (Agglutination) }\end{array}$ & $\begin{array}{l}\text { Can have partial or full fusion, } \\
\text { may have difficultly urinating, } \\
\text { recurrent UTIs/infections, } \\
\text { pulling sensation. }\end{array}$ & Visual inspection & $\begin{array}{l}\text { No treatment necessary if } \\
\text { asymptomatic. Vulvar care guidelines. } \\
\text { Topical estrogen +/- topical steroids. } \\
\text { Surgical correction is RARELY necessary [10] }\end{array}$ \\
\hline Lichen Sclerosis & $\begin{array}{l}\text { White lesion, typically } \\
\text { in a butterfly configuration } \\
\text { with whitened skin } \\
\text { circumscribing the vulvar and } \\
\text { perianal areas }\end{array}$ & $\begin{array}{l}\text { Visual inspection, biopsy } \\
\text { confirmation not required } \\
\text { in pediatric patients. }\end{array}$ & $\begin{array}{l}\text { Super-potent topical steroid daily for } \\
6 \text { weeks, with taper [11]. May need } \\
\text { maintenance therapy. }\end{array}$ \\
\hline $\begin{array}{l}\text { Non-sexually } \\
\text { transmitted } \\
\text { ulcers } \\
\text { ("aphthous } \\
\text { ulcers") }\end{array}$ & $\begin{array}{l}\text { One or more painful ulcers } \\
\text { with raised edges and } \\
\text { purulent bases, often } \\
\text { accompanied by systemic } \\
\text { symptoms }\end{array}$ & $\begin{array}{l}\text { Rule out sexually transmitted origin. } \\
\text { Viral etiology often not determined, } \\
\text { can test for EBV, CMV, or influenza A }\end{array}$ & $\begin{array}{l}\text { Treat symptomatically with topical } \\
\text { anesthetics and pain control; may } \\
\text { require antibiotics if appears } \\
\text { super-infected. Generally } \\
\text { self-resolve in 2-3 weeks. }\end{array}$ \\
\hline Pinworms & $\begin{array}{l}\text { Pruritis ani or perianal } \\
\text { itching, classically } \\
\text { at night. }\end{array}$ & Scotch tape test or visual inspection & $\begin{array}{l}\text { Single } 100 \mathrm{mg} \text { dose Mebendazole } \\
\text { or Albendazole. Repeat in } 2 \\
\text { weeks if needed. }\end{array}$ \\
\hline $\begin{array}{l}\text { Seborrheic } \\
\text { dermatosis }\end{array}$ & $\begin{array}{l}\text { Erythematous and greasy, } \\
\text { yellowish scaling on vulva and } \\
\text { labia-crural folds associated } \\
\text { with dandruff-type folds } \\
\text { behind ears/face }\end{array}$ & Visual inspection & $\begin{array}{l}\text { Topical clotrimazole with } 1 \% \\
\text { hydrocortisone if needed }\end{array}$ \\
\hline $\begin{array}{l}\text { Streptococcus } \\
\text { pyogenes }\end{array}$ & $\begin{array}{l}\text { Flare of vulvovaginal } \\
\text { complaints with } \\
\text { respiratory infections }\end{array}$ & $\begin{array}{l}\text { Vaginal cultures should be obtained } \\
\text { if discharge is purulent or } \\
\text { persistent }\end{array}$ & $\begin{array}{l}\text { Penicillin or similar } \\
\text { antibiotic }\end{array}$ \\
\hline
\end{tabular}


adoption of proper vulvar care by the patient and her parents, with the caveat that some specific causes may require antibiotics, topical steroids, topical hormones, or other pharmacologic intervention. If, after a thorough history is obtained and physical examination of the vulva is performed, the physician is unable to identify a cause of the child's symptoms, conservative therapy should be started for non-specific vulvovaginitis. For non-specific vulvovaginal complaints, strict adherence to the vulvar care guidelines outlined in the lifestyle section below will lead to relief of symptoms in most children in 2-3 weeks. If symptoms persist after this amount of time, other causes of the vulvovaginitis should be explored and the child should be reevaluated. Even if a specific pathogen is identified, the child will likely get more relief from her symptoms if medical treatment is combined with behavioral support.

\section{Treatment}

\section{Lifestyle}

- Daily warm baths

- Allow child to soak in plain warm water for 10-15 min

- Clean other areas with mild, unscented soap

- Avoid scented soaps, cleansers, and bubble baths

- Finally, clean the vulva, limiting soap use, and rinse well

- Pat dry the vulva after bath or use hair dryer on low/cool heat setting

- Laundry

- Double rinse underwear

- Line-dry underwear or avoid dryer sheets or as dryer sheets leave potentially irritating chemicals in the dryer

- Clothing

- Wear white cotton underwear

- Avoid leggings, tights, and leotards

- Change quickly out of wet swim wear, or sweaty or soiled underwear

- Toileting hygiene

- Wipe front to back—have child demonstrate their understanding

- Wet wipes may be less irritating and more thorough than toilet paper for wiping after bowel movements

- Encourage child to sit with knees apart when urinating to prevent reflux back into vagina-parents may need to purchase a smaller seat or have the child face backward if she is too small to sit with her knees apart on a regular toilet

- Parents should supervise toileting until child can consistently demonstrate proper hygiene

- Do not scratch 
- Take sitz baths in warm water for relief of itching

- Cool compresses may relieve discomfort

- Sleeping

- Do not wear underwear while sleeping

- Choose nightgowns or shorts instead of pajama pants to allow air circulation

\title{
Pharmacologic treatment
}

\section{Antibiotics}

Amoxicillin (oral)[12]

Dosing 25 to $50 \mathrm{mg} / \mathrm{kg} /$ day in divided doses every $8 \mathrm{~h}$

Contraindications hypersensitivity

Interactions BCG, Probenecid, tetracyclines, typhoid vaccine

Main side effects diarrhea

Cost very inexpensive

Antifungals

Corticosteroids

Clotrimazole (topical)[12]

Dosing $1 \%$ ointment applied once or twice daily

Contraindications hypersensitivity

Interactions rare, possibly Xanax

Main side effects skin irritation or rash, edema

Cost inexpensive

\author{
Clobetasol (topical)[12] \\ Dosing $\quad 0.05 \%$ ointment applied daily to weekly \\ Contraindications hypersensitivity \\ Interactions Aldesleukin, Hyaluronidase \\ Main side effects Atrophic striae, local irritation, hyperglycemia, or adrenal suppression \\ Cost inexpensive \\ Dosing $1 \%$ ointment applied two to three times daily, up to four times daily \\ Hydrocortisone (topical) [12]
Contraindications hypersensitivity
Interactions Aldesleukin, Hyaluronidase
Main side effects Atrophic striae, local irritation, hyperglycemia, glucosuria, or adrenal suppression
Cost inexpensive


Estrogens

\begin{aligned} & \multicolumn{2}{c}{ Topical estrogen or estradiol cream[12] } \\ & Dosing $0.01 \%$ ointment applied twice daily \\ & Contraindications hypersensitivity, estrogen dependent tumor \\ & Interactions BCG, Probenecid, tetracyclines, typhoid vaccine \\ & Main side effects $\begin{array}{ll}\text { irritation, redness, vulvar hyperpigmentation, minimal vaginal bleeding, and } \\ \text { breast bud formation }\end{array} \\ &$ Cost inexpensive \end{aligned}

Surgical separation of labial adhesions (Fig. 2)

Standard procedure Application of topical anesthetic and mild sedation, as needed, is followed by insertion of a lubricated Q-tip behind the labia minora. The Q-tip is then gently pulled forward along the midline raphe formed by the fused labia minora. Surgery should be followed by topical estrogen cream for 1 to 2 weeks and then application of a bland emollient for 6 to 12 months.

Contraindications Unable to tolerate in office or unable to tolerate anesthesia

Complications Can cause further scarring and should therefore only be performed in those for whom medical management has failed or who have serious symptoms such as complete urinary obstruction

\section{Conclusion}

Vulvovaginitis is a disruptive problem that is by definition irritating or painful but can also be distracting or embarrassing for a young child. The overwhelming majority of vulvovaginal complaints are due to local irritants and behaviors that can be modified. Thus, most cases can be treated conservatively and most of the patient should see improvement in their symptoms in 2-3 weeks after adopting the vulvar care guidelines outlined in this chapter. For the remaining cases that have a specific cause, treatment is dependent on accurate diagnosis. Therefore, any child without improving symptoms after behavioral modifications should be reevaluated.

Vulvovaginitis is the most common reason for a young girl to visit a pediatric gynecologist, but fortunately, this complaint can almost always be treated without complex medical or surgical intervention; just a few simple changes to the child's habits can have an enormous impact on their symptoms and how they feel on a day-to-day basis. 


\section{Compliance with Ethical Standards}

\section{Conflict of Interest}

Chelsea Bayer and Laura Parks declare that they have no conflict of interest.

Human and Animal Rights and Informed Consent

This article does not contain any studies with human or animal subjects performed by any of the authors.

\section{References and Recommended Reading}

1. Joishy M, Ashtekar CS, Jain A, Gonsalves R. Do we need to treat vulvovaginitis in prepubertal girls? BMJ. 2005;330:186

2. Hoefgen, Holly R., and Diane F. Merritt. "Vulvovaginitis." Nelson Textbook of Pediatrics. Philadelphia: W.B. Saunders, 2000. 2607-613.

3. Garden AS. Vulvovaginitis and other common childhood gynaecological conditions. Arch Dis Child Educ Pract Ed. 2011;96:73.

4. Piippo S, Lenko H, Vuento R. Vulvar symptoms in paediatric and adolescent patients. Acta Paediatr. 2000;89:431.

5. Yilmaz AE, Celik N, Soylu G, et al. Comparison of clinical and microbiological features of vulvovaginitis in prepubertal and pubertal girls. J Formos Med Assoc. 2012;111:392.

6. Farhi D, Wendling J, Molinari E, et al. Non-sexually related acute genital ulcers in 13 pubertal girls: a clinical and microbiological study. Arch Dermatol. 2009; 145:38.
7. National guideline for the management of vulvovaginal candidiasis. Clinical Effectiveness Group (Association of Genitourinary Medicine and the Medical Society for the Study of Venereal Diseases). Sex Transm Infect 1999; 75 Suppl 1:S19.

8. Maw RD. Treatment of anogenital warts. Dermatol Clin. 1998; $16: 829$.

9. Kraus SJ, Stone KM. Management of genital infection caused by human papillomavirus. Rev Infect Dis. 1990;12 Suppl 6:S620.

10. Bacon JL, Romano ME, Quint EH. Clinical recommendation: labial adhesions. J Pediatr Adolesc Gynecol. 2015;28:405.

11. Casey GA, Cooper SM, Powell JJ. Treatment of vulvar lichen sclerosus with topical corticosteroids in children: a study of 72 children. Clin Exp Dermatol. 2015;40:289.

12. Red book: pharmacy's fundamental reference. Montvale, NJ: Thomson Reuters, 2010. Print. 